\title{
Technology Roadmapping Architecture Based on Knowledge Management: Case Study for Improved Indigenous Coffee Production from Guerrero, Mexico
}

\author{
D. I. Contreras-Medina ${ }^{(D,}$, E. Sánchez Osorio, L. A. Olvera Vargas, and Y. Romero Romero \\ CONACYT Research Fellow-Centro de Investigación y Asistencia en Tecnología y Diseño del Estado de Jalisco A.C. CIATEJ, Av. de los \\ Normalistas No. 800, Colinas de La Normal, Guadalajara, Jalisco Post Code 44270, Mexico
}

Correspondence should be addressed to D. I. Contreras-Medina; dcontreras@ciatej.mx

Received 24 December 2018; Accepted 7 March 2019; Published 9 May 2019

Guest Editor: Jesus R. Millan-Almaraz

Copyright ( 2019 D. I. Contreras-Medina et al. This is an open access article distributed under the Creative Commons Attribution License, which permits unrestricted use, distribution, and reproduction in any medium, provided the original work is properly cited.

\begin{abstract}
Having demonstrated its importance for economic and human developments, technological change is considered one of the biggest supports worldwide. Today, with the population increase, the inclusion of technology is considered the most appropriate way to reduce the impact of this challenge. Considering 171 indigenous coffee producers from Paraje Montero and Tierra Colorada from Guerrero, Mexico, the present study proposes technological routes for the indigenous coffee production chain and the inclusion of emerging technologies such as sensors, actuators, and processing devices basing on the requirements of the chain. During face-to-face sessions, questionaries, field visits, and literature review for knowledge management, the results expose the need of effective actions against diseases and the reduction of climate change, lack of infrastructure, old plantations, and lack of commercialization channels; for these and considering the requirement of greenhouse technology by indigenous coffee producers and following the labor value driver of the digital compass, the necessity of several kinds of sensors, technologies, and methodologies has been identified with high possibilities to be implemented by similar producers analyzed in this manuscript to help in solving the problems identified in this work. The combination of remote sensing, signal processing, and spectroscopy could be employed to explore mineralogical features of soil and help problems with fertilization; sensor modules to collect temperature, humidity, and light intensity data are a priority for greenhouse monitoring; electrochemical sensors and optical technologies could be of great help to detect the presence of diseases in coffee plants; and the installation of a greenhouse solar dryer is necessary to reduce the time of the sun drying process and protect the coffee cherry. These emerging technologies will help to improve the production of coffee. The study contributes to identify a technology roadmap proposing technological implements according to indigenous coffee production chain requirements and serves as support for future studies in indigenous regions.
\end{abstract}

\section{Introduction}

Historically, the steam machine, infrastructure to get mass and automated production, and currently, the interconnected cyber physical systems, tools, machines, and products used as sensors to gather information for optimal decisionmaking [1] are, and will continue be, one of the biggest supports for economic development and human progress. The connectivity systems, automation, monitoring, and digital performance of the manufacturing industry [2] are some aspects which are parts of industry 4.0 are intensively researched by other areas such as agriculture; this results in the emergence of the term agriculture 4.0 [3].

Agriculture 4.0 is characterized by the integration of information technology and communications with agricultural production [4]; it is a part of currently technological evolution, and today, the challenge to produce, environmentally friendly, a higher quantity of high-quality food is greater due to a continuous growing population, economic crisis, and continuous changing climate [5-7]. The contribution of agriculture 4.0 on reducing the impact of these problems becomes fundamental to continue supporting economic 
development and human progress. In this sense, the central idea is to fuse information technology and communications in emerging technologies such as sensors, signal processing modules, and precision technology to help in solving the aforementioned problems and also to incorporate them to production chains [3]. Information technology and communication have helped to solve problems in agriculture. For example, for pest control, a WSN (wireless sensor network) with energy efficiency was used to capture the sound caused by a pest; this sound was later aggregated to cluster head to be conveyed, at the end, to the cluster station [8], in order to send an alarm to control the pest in the coffee crop. In the same way, technology has been used at the end of the supply chain of coffee; an example of this is a colorimetric sensor to evaluate the quality and to identify classification patterns of ground roasted, espresso, and aeroespresso coffees; these kinds of coffees were sorted by categories such as variety and roast degree of coffee beans [9]. The importance of incorporating technology to a production chain is fundamental because it increases the value of the products; an example of this is the work presented by [10] and the work to evaluate the impact of genotype and environment on coffee quality [11]. In those works, it was important to evaluate, as quantitative as possible, the quality of coffee; therefore, it necessitates the use of the electronic nose, volatile organic compound sensors, and colorimetric sensors $[8,12]$.

Defined as the interaction of companies or individuals to supply goods and services, the production chain [13], in agriculture, begins with the so-called small farmers, going to the industry for transformation, to finish with the customer's purchase. This is the sequence of most agriculture production chains, in the context of developing countries. With around 500 million in the world, small farmers [14] are considered the base of the chain and the support pivot to face the worldwide challenges not only for developing countries. One of the crops that is produced in several cases by peasants and indigenous people is coffee. The worldwide coffee production is involved in a set of challenges along the process: for example, the necessity of better processing practices for increasing sustainable productivity and value-added products of coffee products are just some of the problems of the base of the chain [15].

Coffee is one of the most representative crops in the world because of its cultural, social, and economic impacts around the world. From its origin in Africa around the $6^{\text {th }}$ century, the spread in coffee production, around the world, has been vertiginous and at present provides a livelihood for around 125 million human beings [16]. With a worldwide production of over 9480 million of tons during the period 2017-18, its importance has transcended in benefit for health [17] and continues playing an important role in socioeconomic environment [18]. In Mexico, the coffee sector had a production of over 800,000 tons in 2017; this included over 500,000 producers of which over $60 \%$ are considered indigenous people from 400 municipalities in 15 states [19]. The coffee sector in México has a set of challenges such as low productivity, increasing cost, low profits, limited research, and by consequence, weak technology transfer [20]. The necessity to take advantage of emerging technologies to help to increase the yield for transforming these challenges into opportunities [3] is required. For example, it is necessary to have automated greenhouses for monitoring crop variables and nutritional variables using sensors to optimize the production, decrease the cost, and improve the quality of the products [21], or at the end of the supply chain, the use of sensors is necessary to increase the quality of the processed product. To reach this technological development, an alternative is the network alliances with leading technology providers for supplying capital, service investment, and precision farming methods [22]. Even though the necessity of technology incorporation is evident, the technological challenges are not the same for all the coffee industries around the world, and an analysis of the problems in this industry is needed in order to preserve all the benefits that this crop brings to persons.

At present, many methodologies exist for analyzing emerging technologies and provide a technological solution to problems that could represent a threat in agriculture and the coffee industry in some years; these include assessments, foresight, and technology intelligence [23], but one of the approaches that consider the economic, social, and environmental contexts and technological evolution is "technological roadmapping." Technological roadmapping, developed in the last century, is an approach that helps to identify relationships between existing context and developing technologies, aligning technology with perspectives to achieve innovation $[24,25]$ and solve problems. Technological roadmapping has the facility for adapting to different contexts, considering internal and external resources, and has become a powerful instrument to establish technological routes to get innovation $[24,26]$, and its structure includes three phases: (1) future vision, (2) current situation, and (3) the best route to get the future vision since current situation [25]. This is in line with innovations' definition of the combinations of knowledge, equipment, resources, and other external factors [27]. The current status helps technological roadmapping to focus the efforts. In this case, the present-day status of agriculture in the world and according to [28], in China, there are two main problems, the scarcity of arable land and the unbalance supply and demand on the water resource; therefore, the technology needs to be developed towards solving these problems. In México, the water demand is a problem too, because there is an imbalance in water supply; this is because $50 \%$ of rain water falls in the southeast of the country [29]; so, there is the necessity of developing technology towards solving the problem of water scarcity in several places in México where the rain is limited. Another proposed option is to develop plants through the use of biotechnology tools, which survive under water scarcity conditions without affecting their yield [30]. Therefore, the technological roadmapping in agriculture needs to be focused on proposing sensors, actuators, processing systems, and biotechnological tools, which help solve problems that are presented now and, in the future, could represent a serious threat to food safety in México and around the world.

In this sense, innovation, which is a part of technological roadmapping, is considered as social activity that combined intangible and tangible assets. This forces us to 
think that the innovation process inherently must consider experience and perspectives of people: tacit knowledge, formal structures, and explicit resources such as explicit knowledge. Considered an activity that creates new knowledge through the interaction between tacit and explicit knowledges, knowledge management $[31,32]$ is also a fundamental piece of analysis for strategic decision-making within different scenarios [33-35]. Although this approach does not increase the collaboration per se, it does create a shared context according to who participates and how they participate in order to develop technology that really could be implemented in real life to solve real problems [26]. Knowledge management has not been employed correctly in the application of Information and Communications Technology (ICT). Several developments based on ICT fail in capturing tacit knowledge and the real necessities of the farms. Another problem of ICT is the absence of linkage between tacit and explicit knowledges of farmers that is reflected in the low utility of these technological developments. In Sweden, the use of AgriDSS, which is an information and communication-based technology that supports the decision-maker, cannot be fully employed because, in summary, it does not involve the expressed needs of crops and the tacit knowledge of growers [36]. Therefore, there is the necessity of studies that combine emerging technologies and status of the agriculture production chain, taking into account the perspectives and tacit knowledge of growers of the region of interest, principally those belonging to the most vulnerable groups to focus the efforts on developing the technology that really helps in solving these problems.

Reference [37] proposed a short-term roadmap; the study proposed to improve the production, flow and access to information and knowledge; decentralization, knowledge sharing across the boundaries; and be recognized, in human resources, as an employer that implements best practices. For this, strategies were proposed to take advantage of technology in communication and the implementation of universal platforms to make an extensive network, support the execution of projects, and allow the interaction of the actors, to be more inclusive and to enhance the capacity to perform and to innovate through the knowledge sharing for the agriculture sector. This proposal was basing on a review of surveys, case studies, and the collaboration of key partners. This kind of studies are necessary in regions where technology needs to be implemented in order to focus the efforts correctly. In this sense, [38], basing on the framework of climate conditions and to get the goals of National Water Resource Strategy 2 (NWRS2), draws a national roadmap about the collaboration of universities and research institutions from South Africa in the topic water management in agriculture, proposing the inclusion of technologies such as (1) plant physiology, genetics, and molecular genomics for increasing the productivity and efficiency of crops by employing and monitoring the physiological status of plants the use of water could be more efficient; (2) the conservation tillage, intercrops, manure, and compost to improve agricultural practices; (3) rainwater reservoirs for harvesting and monitoring of water irrigation, precision agriculture, and
GPS technologies to control water application; and (4) economic, life-cycle assessment, and crop growth models for sustainability research. An example of technology that can be employed in the roadmap of the aforementioned study is the employment of some elicitors to increase significantly the levels of flavonoids in lettuce [39]; this compound is presented when the plants suffer drought. The increase of flavonoid levels is directly related to the drought tolerance which can be measured by using sensors for monitoring plant physiology such as that presented by [40] where a transpiration of plants is measured by employing temperature, humidity, radiation, and flux sensors. As aforementioned, the water scarcity is now a problem; so, the rain water collected in greenhouses is an option to save water, and it has been successfully employed for growing vegetables [41]. The water collected can be used by irrigation systems in a controlled way based on measuring plant variables, soil variables, or thermal variables. In the review presented by [42], a ground-based thermal remote sensor is used to estimate drought stress and evapotranspiration, and it is used for irrigation; a similar work is presented by [43] where an automated irrigation system was developed based on wireless sensor monitoring of temperature and soil moisture near the root zone of the plants. The aforementioned works converge to solve problems elucidated by the roadmap of the aforementioned study. The conclusion here is to employ and develop technologies suggested by studies such as those realized by [38] in South Africa in order to focus the efforts. In the case of Mexico and around the world, similar problems have been identified; however, it is necessary to achieve more regional studies to involve a real context in roadmapping studies.

In more advanced studies, [44] performs a roadmap to evaluate the production of sustainable electric power from agricultural biomass, basing on statistical data and the applications of equations; also, [44] shows a sequence to evaluate the potential of gross biomass, surplus biomass, bioenergy, and biomass power of residues of cereal crops, sugarcane, and cotton from India through direct combustion technology. Without deepening in technological aspects, the study proposes the installation of biomass power plants and the preparation of a robust business model due to constraints to obtain the gross biomass in the real world. In this sense, [45] presents a roadmap to define a pathway for a sustainable energy industry based on the harmonization of upstream and downstream of palm oil agricultural activities in Malaysia. Considering literature review and field survey, three dimensions were considered: resource supply, conversion technology, and network systems. This study mentioned as priorities the design of innovative options, incentives for biomass-to-energy conversion in a short-term period, creation of a fuel hub to ensure the fuel supply of mills in a medium-term period, upgrade of ageing infrastructure in remote sites, and extension of connection lines. In the area of agricultural biomass for generation of energy, several kinds of sensors have been used to help the biomass monitoring in order to increase the quantity of biomass; in [46], it is presented as a technique based on amperometry that increases the reliability, rapidity, and automation of measurements for algal biomass determination. In the case of 
the energy that comes from digestion, presented in [47] is a system that includes electrical power supply that comes from anaerobic digestion biomass; this work consists of a device based on superconducting magnetic energy which serves as storage of the electrical energy; this device tries to overcome the blackout of energy and helps to know the quantity of demanded energy by the network when this demand increases. In this work, several variables of the anaerobic reactor were monitored by using several kinds of sensors such as temperature, volatile fatty acids, alkalinity, ratio VFA/alkalinity, carbon/nitrogen ratio, concentration of ammonia, and $\mathrm{pH}$.

In the coffee sector, technological integration has been addressed through the roadmapping approach by different countries and organizations around the world. One example is the study of [48], which presented a five-year action plan in the coffee sector. Technological strategies were upgrading information technology (IT) solutions for data management to increase efficiency of data input, handling, storage, and dissemination; organizing activities on ICO website and webinars on coffee-related matters; and supporting research and development of new technologies, to facilitate projects. In this sense, [49] launched coffee roadmap that include priority activities through technological aspects as creation and multiplication of resistant varieties, for building a sustainable coffee production; establish an information system and weather monitoring and the use of rain water harvesting, for adaption to climate change; promote environmentally sound primary postharvest, for value addition; improve market access, for market development; and implement units, for project management. Reference [50] launched a national coffee roadmap to improve quality of coffee. In this, technological aspects were included such as the provision of agricultural machineries such as dryers, dehullers, depulpers, and grinders for postharvest facilities; establishment of coffee nursery; and the creation of a production database. There are some cases where technology has been adopted in the coffee industry; for example, in production, [51] developed technologies to improve coffee varieties resistant against coffee leaf rust, reducing production cost by up $60 \%$. In addition, this organization is helping to adopt modern technologies to produce many seedlings through the project "weaning nurseries" for increase yields and plant protection. In monitoring, taking advantage of the camera and GPS location and the use of smartphone applications for providing a specific solution against pests and diseases through image analysis of a plant start to be an option due to the number of users in the world [52]. In connectivity, the IFA Krishi (android-based mobile application) is being very useful for coffee rural agriculture. Providing news, fertilizer calculations, and remedies to combat the pest and diseases and serving as a platform to post farmer enquiries, solutions from experts, market prices, and trader information, the farmers are connected with other organizations and with the government. The use of this technology has resulted in an increase of almost 20 per cent in its production [53]. In sustainable management, [54] developed the sustainable land management (SLM) technology for adapting to climate changes. Stone lines and Fanya Juu are two proved sustainable strategies to increase and slow down runoff water infiltration, besides terrace construction to increase the production and stop erosion.

All the aforementioned cases are successful studies about implementation of technology to solve a problem which sometimes is identified by roadmap studies; however, most of the studies about the inclusion of emerging technologies in the agricultural sector are usually reduced to the technical approach. For example, [55] presents a sensor to measure electrical conductivity, depth of the ground, elevation, and georeferencing to expose the covariations among these variables and electrical conductivity. This study employs a mapping spatial analysis to explain the total variability. Reference [56], using MODIS sensor, evaluated the effectiveness of coffee mapping in Brazil, through the images of the sensor. Reference [57] considered a Mandani-Fuzzy logic model as a tool for monitoring and selecting, at the industrial level, an appropriated dry mill process in coffee production in Veracruz. Reference [58] developed and optimized an algorithm of sensor node deployment, for agricultural monitoring. Reference [59] developed an authentication protocol using wireless sensor networks (WSNs) to protect the data of temperature, soil, humidity, light, and soil $\mathrm{pH}$ also for agriculture monitoring, while [60] exposed a nanofertilizer to combat the pest and diseases.

Worldwide challenges force us to think in new ways to modernize practice production, lower production cost, increase plant protection, and improve market access to get sustainable agriculture $[61,62]$. In this sense, the incorporation of emerging technologies along the production chain has been beneficial in many cases. However, in most cases, the adoption of technology by producers is difficult even though the roadmaps make imperative the use of technology to improve the production in agriculture and more specifically to increase the coffee production. The studies about the inclusion of emerging technologies in agriculture and more specifically to the coffee industry supply chain are difficult because the works usually are reduced to technical approaches, and in most cases, the final user of these technologies is not considered at the moment of designing them. In the work presented by [63], a case of studio of the factors that compromise the acquisition of information technologies with coffee producers can be condensed as financial limitations, low education level in operating computers, deficiencies of technological resources, noncoincidence of schedules between the instructor and computer operators, complexity of computer software, etc. Those, in general, are problems suffered by several small producers of coffee in México and need to be considered at the moment of developing technological roadmap of the regions of interest.

Technological change is here to stay, devising directions to address the worldwide challenges and reach a sustainable agriculture. This study recognizes the contributions of many researches to include technologies into the agricultural sector, but the evidence still shows that it is imperative to devise technological routes to line up with emerging technologies according to the needs and perspectives of those disadvantages and in marginal 
condition groups, also considering the final user and the real crop necessities. Taking into account the technology roadmapping structure, to explore technological routes [25], and knowledge management methodology, to look at indigenous knowledge [32], the aim of this study is to establish technological routes including emerging technologies along the indigenous coffee production chain basing on perspectives and needs of their producers.

This document starts with Introduction. The aspects of technology evolution and the emergence of agriculture 4.0 were addressed. Worldwide challenges and the importance of fusing emerging technologies along the agricultural production chain to face them are exposed. Considering the coffee production chain as a base, its transcendence, history, production problems, and the importance of a small producer from the indigenous context as a case of study are also exposed. Studies related to technological integration for agriculture and the coffee sector; the emerging technology approach and its benefits are also registered and analyzed.

Materials and Methods was also addressed. This exposed information gathering about location, time, study sample, methodology elements for the knowledge creating process, and the technology roadmapping structure. Information Analysis and Validity is also registered. For Results and Discussion, environmental and individual descriptions of indigenous coffee producers, sequence of indigenous coffee production chain, and the findings of desired future and current situations of the coffee production chain are exposed. A proposal for a technological route including emerging technologies for the indigenous coffee production chain as a case of study is also registered. Conclusions with analysis about the findings of the indigenous coffee production chain is exposed as the last part of the manuscript.

\section{Materials and Methods}

2.1. Information Gathering. Technological study was carried out with 171 indigenous coffee producers from the communities of Paraje Montero and Tierra Colorada from Malinaltepec, Guerrero, Mexico, during the period that goes from March to November 2017. Information gathering was following the three methodology elements of the knowledge creating process: (1) context-knowledge place; (2) knowledge conversion process; and (3) moderator, from $[25,32]$ for making explicit the roadmapping routes, and digital compass of [64] for gathering technology dimensions. The first two methodologies have been used in different studies under several approaches [65-68], while the third have been used for aligning value drivers with industry 4.0 [64].

For this study, indigenous coffee producers were aware about the objective of the study and asked whether they were willing to participate in it. If they agreed, they were asked to stay in the space of session; conversely, if the coffee producer does not want to participate, they were free to leave the space. This determination is in accordance with article six, about the autonomy to adopt by theirselves' decisions, of the Law of Recognition, Right and Culture of the Indigenous Peoples and Communities of the State of Guerrero [69].

\subsection{Knowledge Creating Process}

2.2.1. Context-Knowledge Place and Persons. For the study, the context-knowledge place was defined as a shared context in which knowledge is created, shared, and utilized; this was the first element considered for knowledge conversion. Due to the cultural and social contexts, it is important to express tacit knowledge and be in contact with their environment and with their people [32]; the study was developed in the spaces assigned by the local authority in each community, to explore, in a face-to-face session, tacit knowledge of indigenous coffee producers and become explicit. This decision was to provide a safe space for coffee producers and collaborators due to insecurity problems of those living in the state of Guerrero.

To explore local resources and the knowledge assets, context-knowledge place information was gathered through two dimensions: environmental (macro level) and individual (micro level) of the indigenous coffee producer. At the macro level, location, altitude, current population, and infrastructure of each community were gathered through literature review and field visits. For this, the questions were as follows: Where is the location of the community? What is the altitude of the community? What is the number of the current population? What is the infrastructure of the community? In the same way, at the micro level, information such as the male or female gender, age, members per family, coffee species crops, area of coffee crop, crop combination, coffee production level, and their process of coffee production were gathered through questionaries' applications and field visits. For this, the questions were as follows: Which is your gender, male or female? What is your age? How many members make up your family? What is the species of coffee that you currently cultivate? What is the area of coffee that you currently cultivate? Do you grow other food besides coffee in the same area? What was your level of coffee production for the last harvest? How do you produce coffee?

\subsubsection{Knowledge Conversion Process: Tacit to Explicit. Tacit} knowledge was gathered through the experience and perspectives of indigenous coffee producers about the status of the coffee production chain in the region. To get this, international and national literature reviews about problems and needs in the coffee sector and national and state production statistics were gathered and presented to indigenous coffee producers, to validate, adjust, or invalidate, basing on experiences and perspectives of indigenous coffee producers, trying to resolve coffee production status, following Othello's metaphor of the wrong diagnosis [70], and according to the conversion of tacit to explicit knowledge on the sequential use of metaphor, analogy, and model [32].

To facilitate the responses of validation, adjustment, or invalidation of the information presented to coffee producers, analogy of medical consultation was considered. During the medical consultation, the current status and clinical history are taken into account to get an accurate diagnosis and healthy patient; this analogy was applied in indigenous coffee production, through the exploration of current status and the background of this sector to identify problems and 
needs to get a specific strategy and improve the production. These problems and needs could be related to processing practices, value addition, low productivity, increasing cost, low profits, weak technology transfer, and limited research, and the decrease of production statistics as surface planted, harvest surface, and production in the period 2008-2017. To get diagnostic solution was to devise technological routes to achieve an increase on the production based on the current status and perspectives of indigenous coffee producers.

In this sense, explicit knowledge was gathered following the previous analogy and formalized according to the roadmapping structure [25]. To improve the production, the coffee sector was asked first: What could be the future of coffee production in the region? The current status was explored exposing historical problems and needs besides statistics review to validate, adjust, or invalidate, under the question: What is the current situation of coffee production in the region? And for diagnostic solution and devise of technological routes, the question was posed: Which will be the best route to reach desired future of the coffee production chain since the current situation? (see Figure 1).

Having the technology roadmapping explicit, digital compass of [64] was considered to match technological tools with technological routes for indigenous coffee production from the communities of Paraje Montero and Tierra Colorada from Malinaltepec, Guerrero, Mexico. For selecting the specific technological tools, the value driver was selected considering indigenous coffee production chain sequence.

According to [64], a digital compass is formed by eight value drivers and by twenty-six different technological tools. Each value driver establishes a framework that can be leveraged to systematically identify the technological tools that can be used and impact significantly on the performance. For example, the resource/process is focused on improving the process via decreased material consumption; asset utilization is used to make the best use of organization's machinery; labor is centred on improving labor productivity; inventories are focused on reducing excessive supply in stock; quality is used to detect quality inefficiencies for improving quality; supply/demand match is centred on optimizing the supply with the actual demand; time to market is focused on speeding up the development process to reach the market with a new product earlier; and service/aftersales is used to decrease service cost and machine downtimes (see Figure 2).

2.2.3. Moderators. In order to integrate the knowledge conversion process and develop a common language among the participants, a group of research members of the interregional technological prospecting laboratory for the development of food were chosen to develop the sessions; besides, a Spanish-Indigenous Tlapaneco translator was included and assigned by the Secretary of Indigenous Affairs and Afromexican Communities from the State of Guerrero (Spanish translation: Secretaria of Asuntos Indigenas and Comunidades Afromexicanas from Guerrero). The translator was a wellknown person in the communities; the session was developed in Spanish and Indigenous Tlapaneco languages. This was very helpful to gathering tacit and explicit knowledges in indigenous context.
To obtain a high response rate, the coffee indigenous producers were summoned by commissaries of communities through the invitation of the Secretary of Indigenous Affairs and Afromexican Communities from the State of Guerrero.

2.3. Information Analysis and Validity. Explicit information about the desired future, current status, and the best technological route was tabulated, ordered, and registered based on the roadmapping structure by each collaborator. Each response was registered, compared, and analyzed according to its frequency of appearance through the NVIVO v11 ${ }^{\circledR}$ software. The indigenous coffee production chain was analyzed and mapped according to sequence of activities. This was validated through a field visit. Indigenous coffee production chain activities and technology roadmapping were analyzed for choosing value drivers and selecting technological tools according to the digital compass of [64]. In addition, individual and environment information were ordered, registered, tabulated, and analyzed through Microsoft Excel ${ }^{\circledR}$ 2013.

Indigenous origin of participants was validated by local authority and by the representatives of the Secretary of Indigenous Affairs and Afromexican Communities from the State of Guerrero. Face-to-face session, field visits, questionaries' responses, and literature review were validated by collaborators through triangulation of information.

\section{Results and Discussion}

\subsection{Context-Knowledge Place}

3.1.1. Environment (Macro Level). Located at $256.5 \mathrm{~km}$ from Chilpancingo, Guerrero, the Paraje Montero community belonging to the Malinaltepec municipality is situated towards west of Greenwich meridian with Lat: $17^{\circ} 9^{\prime} 48^{\prime \prime} \mathrm{N}$. and Long: $98^{\circ} 42^{\prime} 16^{\prime \prime} \mathrm{W}$. Paraje Montero registers a population of 1146 indigenous inhabitants who speak Tlapanec language and Spanish; also, this community registers kinder garden, primary school, and high school, public lighting infrastructure, telephone booth, public internet, lack of employment, emigration as the main problem, and agriculture as the main economic activity. The Tierra Colorada community from the same municipality, situated towards west of Greenwich meridian with Lat: $17^{\circ} 2^{\prime} 2^{\prime \prime} \mathrm{N}$. and Long: $98^{\circ} 45^{\prime} 31^{\prime \prime}$ W., registers 1027 indigenous inhabitants who speak Tlapanec and Spanish languages; also, this community registers kinder garden, primary school, and high school, public lighting infrastructure, telephone booth, irregularity or dispute related to land tenurity as the main problem, and agriculture as the main activity [71] (see Figure 3).

Paraje Montero has an altitude of 1960 m.a.s.l. while Tierra Colorada registered an altitude of 1122 m.a.s.l. [71], which are within the parameters for optimal growth for the arabica coffee species between 1000 and 2000 m.a.s.l. [72], although it is affirmed that it develops better between 600 and 1200 m.a.s.l. [73].

3.1.2. Individual (Micro Level). The baseline of indigenous demonstrated an elevated percentage of women coffee 


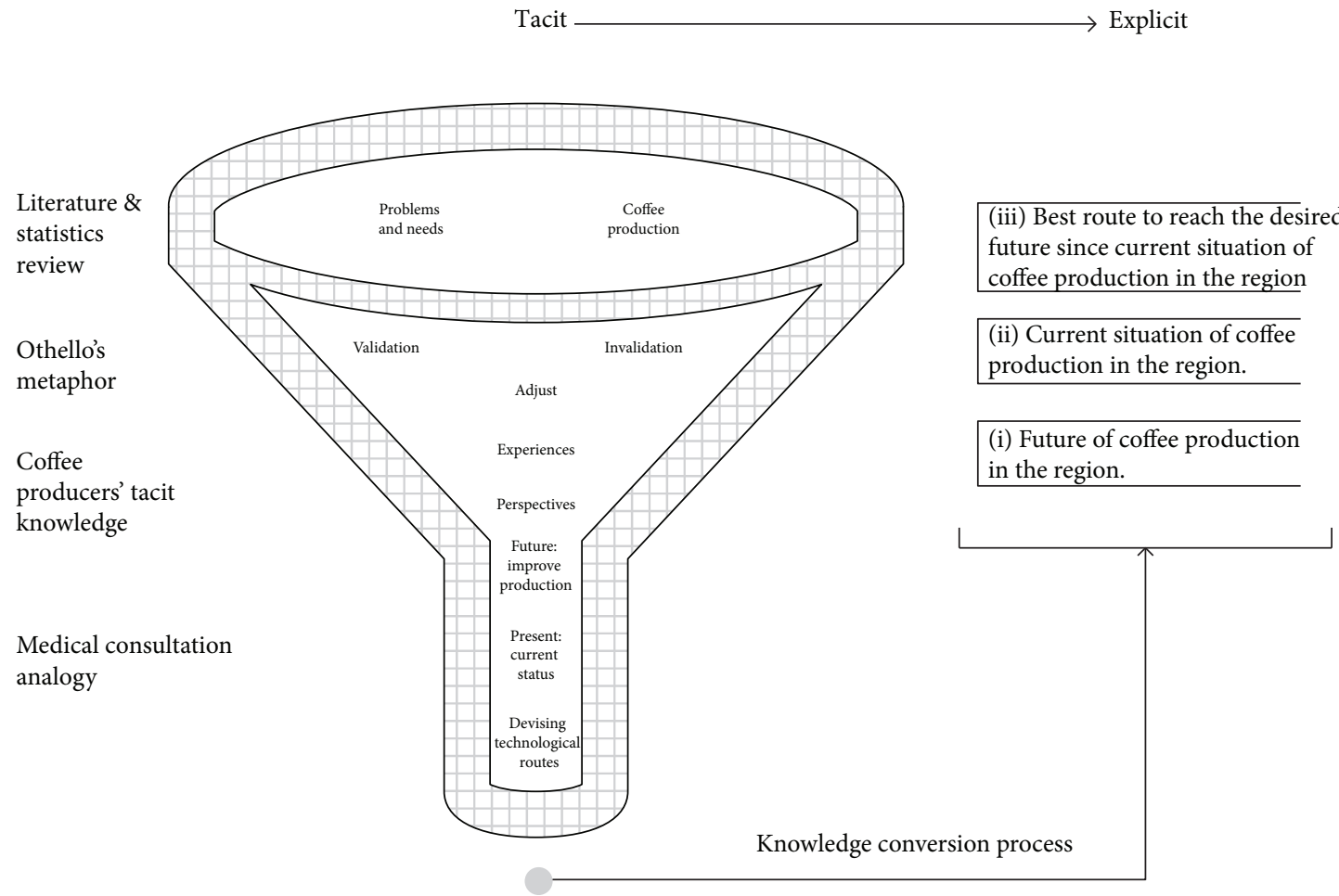

FIGURE 1: Description of the knowledge conversion process. Methodology from tacit to explicit knowledge: for exploring the tacit knowledge, literature and statistics, following Othello's metaphor, and medical consultation analogy were reviewed, while for explicit knowledge, future and current status were explored to get the best route.

producers of coffee arabica with $104(60.8 \%)$ in contrast with men 67 (39.2\%). This is according to conformation trends of several women associations in the region such as the "Indigenous Women of Guerrero Xochineutl" [74] or the project "Spinning our lives" which is a derivative to empower and develop production capacities in women. Here exist strengthened groups such as "group of women Tzú Tzú Colibri," "group of women Kuakualtzin pretty woman," and "group of women heart flower" [75].

The average age is 47.05 years old in women while 49.1 years old in men, with four members per family. This is opposing to the 56-year-old average of coffee producers from other areas but similar to average of 3.8 members per family [76].

The standard area cultivated is 2.07 hectares per producer, combining coffee, corn, and banana crops in the same space. This is in line with the recommendations of cultivating several kinds of crops to improve the pest control, reduce carbon footprint, or moderate agrochemical uses [77].

Crop combination of indigenous coffee producers from Paraje Montero and Tierra Colorada is for the family sustenance. The average sale price of coffee is 0.98 US dollar (19.15 Mexican pesos) per kilogram; this price is above international prices of cherry coffee that is 0.51 US dollar (10.15 Mexican pesos) per kilogram [78].

The average of indigenous coffee production from Paraje Montero and Tierra Colorada is 689 kilograms. This production level is in line with production levels reported of $633 \mathrm{~kg}$ of coffee; however, while these reports are registered by hectare [79], indigenous coffee production from
Paraje Montero and Tierra Colorada is for over two hectares (see Table 1).

The process of the indigenous coffee production chain from Paraje Montero and Tierra Colorada is under conventional production-due to the use of agrochemical products-and is necessary to employ an intensive labor including family support and is formalized as follows: (1) the Secretary of Agriculture, Livestock, Rural Development, Fisheries, and Food (acronym in Spanish: SAGARPA) provides a coffee plant; (2) the indigenous coffee producer seeds the plant in their private area; (3) the indigenous coffee producer cleans, prunes, and fertilizes the plant; (4) the indigenous coffee producer harvests the coffee; (5) coffee beans harvested are translated for sun drying (dry benefit) by the indigenous coffee producer; and (6) the indigenous coffee producer sells to the intermediary buyer capulin coffee beans (see Figure 4). Based on the process of the coffee bean of the agri-food coffee chain in Mexico, the indigenous coffee production chain is contrary to this process because the processes like roasting and grinding are necessary, and due to this, it is incomplete.

3.2. Knowledge Conversion Process: Tacit to Explicit. Indigenous coffee producer experience is based on 20.85 years for men dedicated to planting and growing coffee, while 19.2 years for women. This experience was transmitted through parents and grandparents. This is in line with the study of [80] about the ways of transmitting and managing knowledge for several generations. 


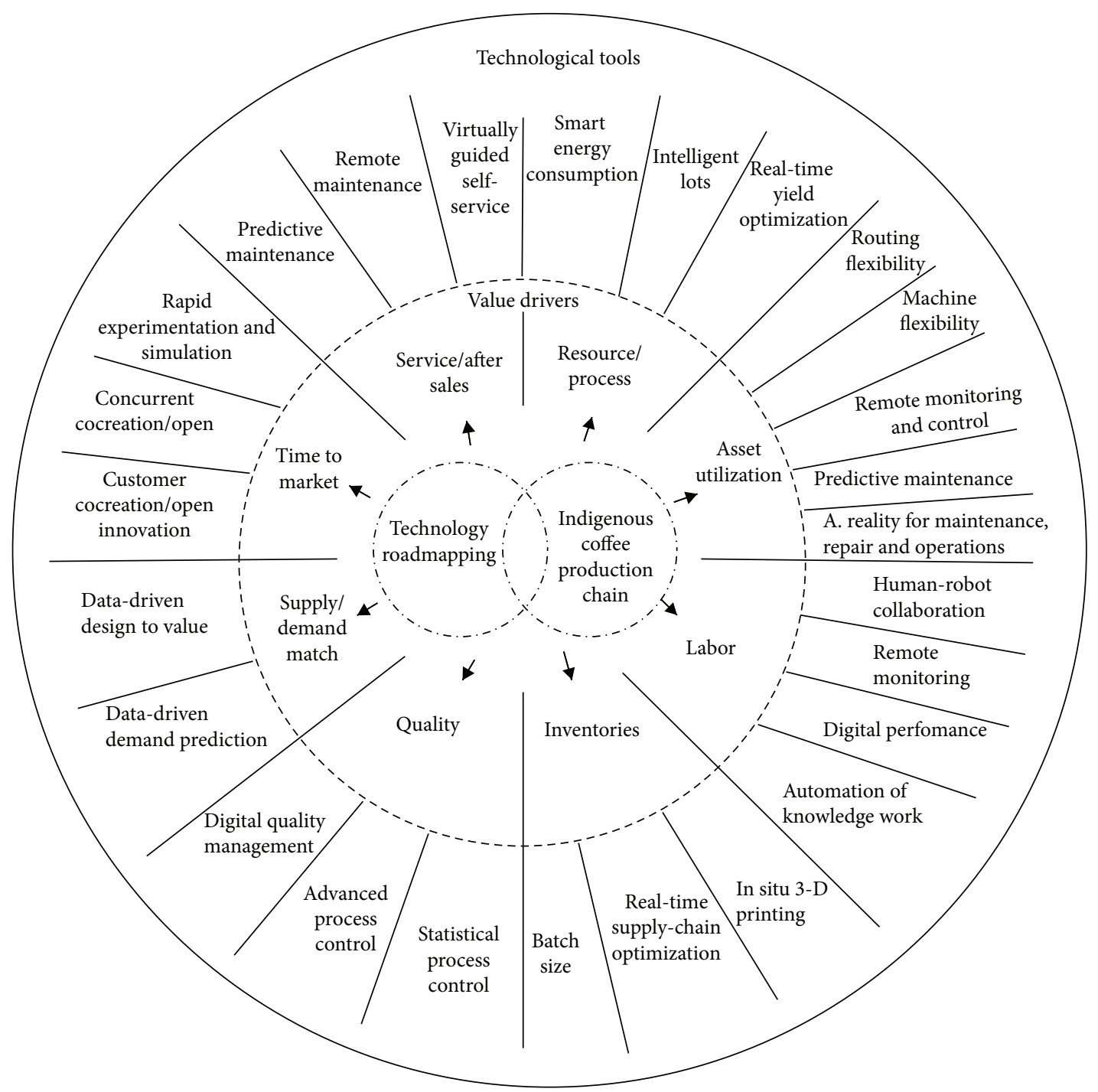

FIGURE 2: Digital compass. Technology tools and value drivers that can be addressed according to technological routes and the indigenous coffee production chain. Extracted from [64].

The experience was formalized through their perspectives about the desired future and current situation of coffee production in the region. The answers about the future were as follows: (1) fight against the pest and diseases as rust, drill, rooster eye, and hanging in coffee with effective actions; (2) better nutrition in the plant; (3) the best advice and monitoring of coffee crops; (4) access to productive credits; (5) renovated coffee plant; (6) training in cultivation and pruning practices; (7) access to infrastructure for grinding and roasting; and (8) opening of commercialization channels for access to new markets.

The current status answers of coffee production were as follows: (1) the high presence of the pest and diseases as rust (Hemileia vastratrix), drill (Hypothenemus hampei), rooster eye (Cercospora coffeicola), and hanging (Rhizoctonia solani) in coffee; (2) severe climate changes; (3) less production of the coffee plant; (4) lack of infrastructure for coffee processing; (5) low sale cost by kilogram; (6) old coffee plantations; and (7) lack of commercialization channels. It is highlighted that there was only one contribution to reach the future since the current situation was in line with the creation of greenhouses.

Previous results about the process of the indigenous coffee production chain from Paraje Montero and Tierra Colorada highlight that the participation of the indigenous coffee producer is important for the development of the process. This reflects a labor-intensive process in the indigenous coffee production chain from Paraje Montero and Tierra Colorada. This is in line with coffee processing in Mexico because this is considered as a labor-intensive system [81].

Basing on previous results about the line of the laborintensive process of the indigenous production chain from Paraje Montero and Tierra Colorada, the value driver of labor must be taken into account. In this sense, technological tools such as human-robot collaboration, remote monitoring, digital performance, and automation of knowledge works must be considered for improved coffee production (see Figure 5). 

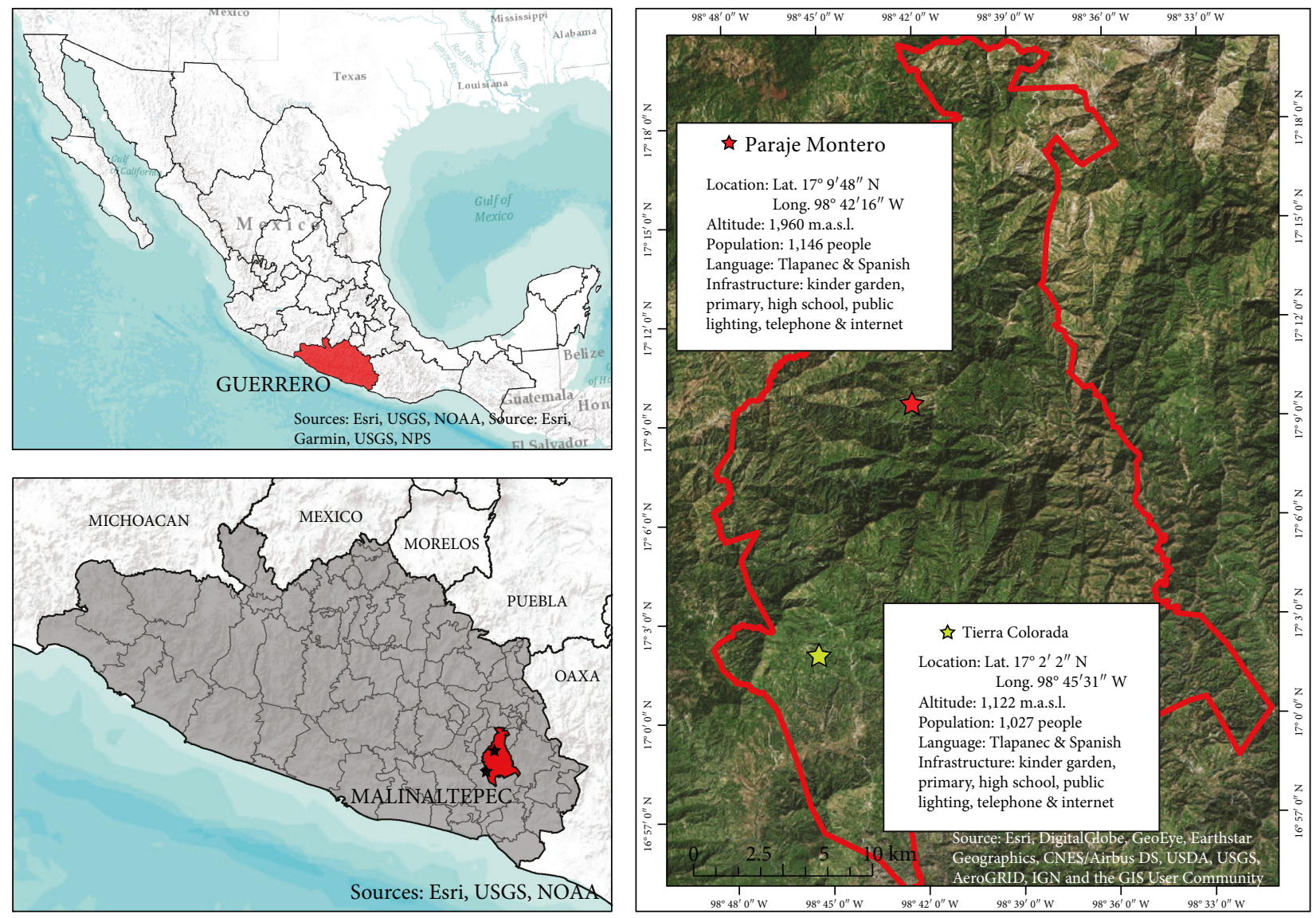

FIgURE 3: Paraje Montero and Tierra Colorada. Details of the macro level of communities in the Guerrero state. Maps were basing on the vectorial data of [94] and communities' location from [95]. For the preparation of the map geographical information system (GIS) Arcmap 10.2.

TABLE 1: Individual micro level or microlevel current status details of indigenous coffee producers from Paraje Montero and Tierra Colorada, Guerrero, Mexico.

\begin{tabular}{lcc}
\hline Micro level & Women & Men \\
\hline Indigenous coffee producers & $60.8 \%$ & $39.2 \%$ \\
Age (average) & 47.05 & 49.1 \\
Member per family & \multicolumn{2}{c}{2.07} \\
Standard area cultivated (ha) & \multicolumn{2}{c}{ Corn and banana } \\
Additional crops & \multicolumn{2}{c}{0.98 US dollar (19.15 } \\
Sale price (kg) & \multicolumn{2}{c}{ Mexican pesos) } \\
Coffee production level (kg) & \multicolumn{2}{c}{689} \\
\hline
\end{tabular}

In this sense, according to the previous results, about the best route to reach the desired future since the current situation of the indigenous coffee production chain of coffee production from Paraje Montero and Tierra Colorada, from Guerrero, Mexico, technology roadmapping requires considering the following technological tools.

(1) Greenhouse. This responds to the necessities of safeguarding the coffee crop against rust and drill, and due to the previous responses, greenhouse creation could be the most accessible strategy for monitoring the coffee plant, renewing old plantations, and increasing production levels (see Figure 6). In this line, according to the environment, current situation, and coffee plant requirement, emerging technologies for installation of greenhouses were recommended for the following purposes:

(a) For seed cultivation, due to the fact that nutrients are primarily uptaken via the roots, many times, a semiopen field greenhouse is enough for the reduction of environmental problems [82]; however, it must first be ensured that the soil provides nutrients for the growth of the plant. Essential elements for the growth of the plant are nitrogen $(\mathrm{N})$, phosphorus $(\mathrm{P})$, potassium $(\mathrm{K})$, calcium $(\mathrm{Ca})$, magnesium $(\mathrm{Mg})$, and sulphur (S) [83]. The presence or absence in the soil of these minerals can be evaluated through remote sensing combining digital imaging and spectroscopy to explore mineralogical features of soil [84] to decide the most suitable space for greenhouse installation. Other options are the hydroponic systems; here, the crop ensures its fertilization 


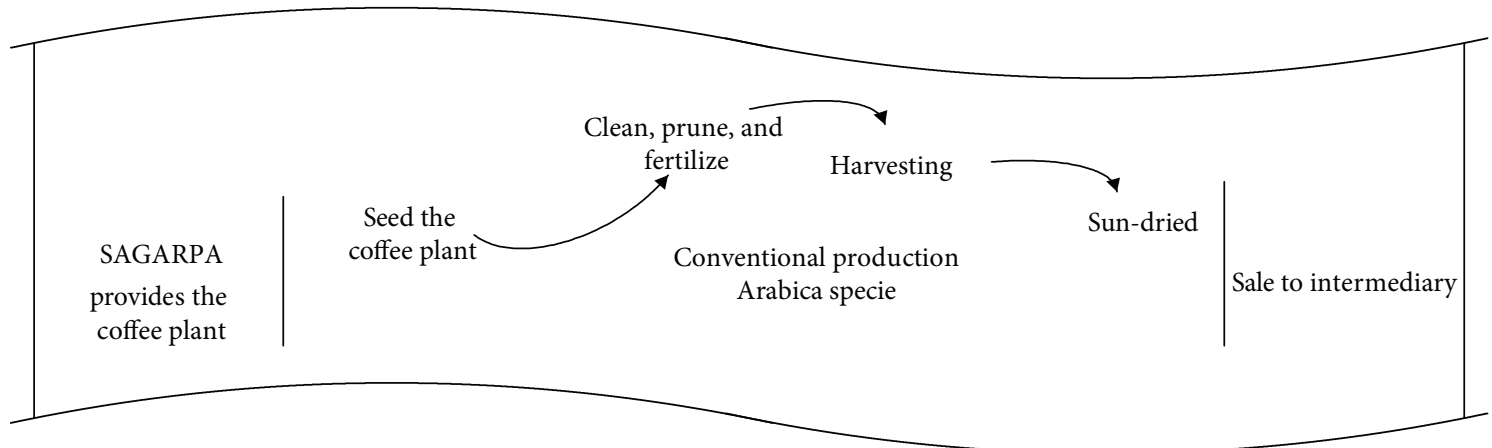

FIGURE 4: Indigenous coffee production chain. Sequence of the indigenous coffee chain from Paraje Montero and Tierra Colorada, Guerrero, Mexico.

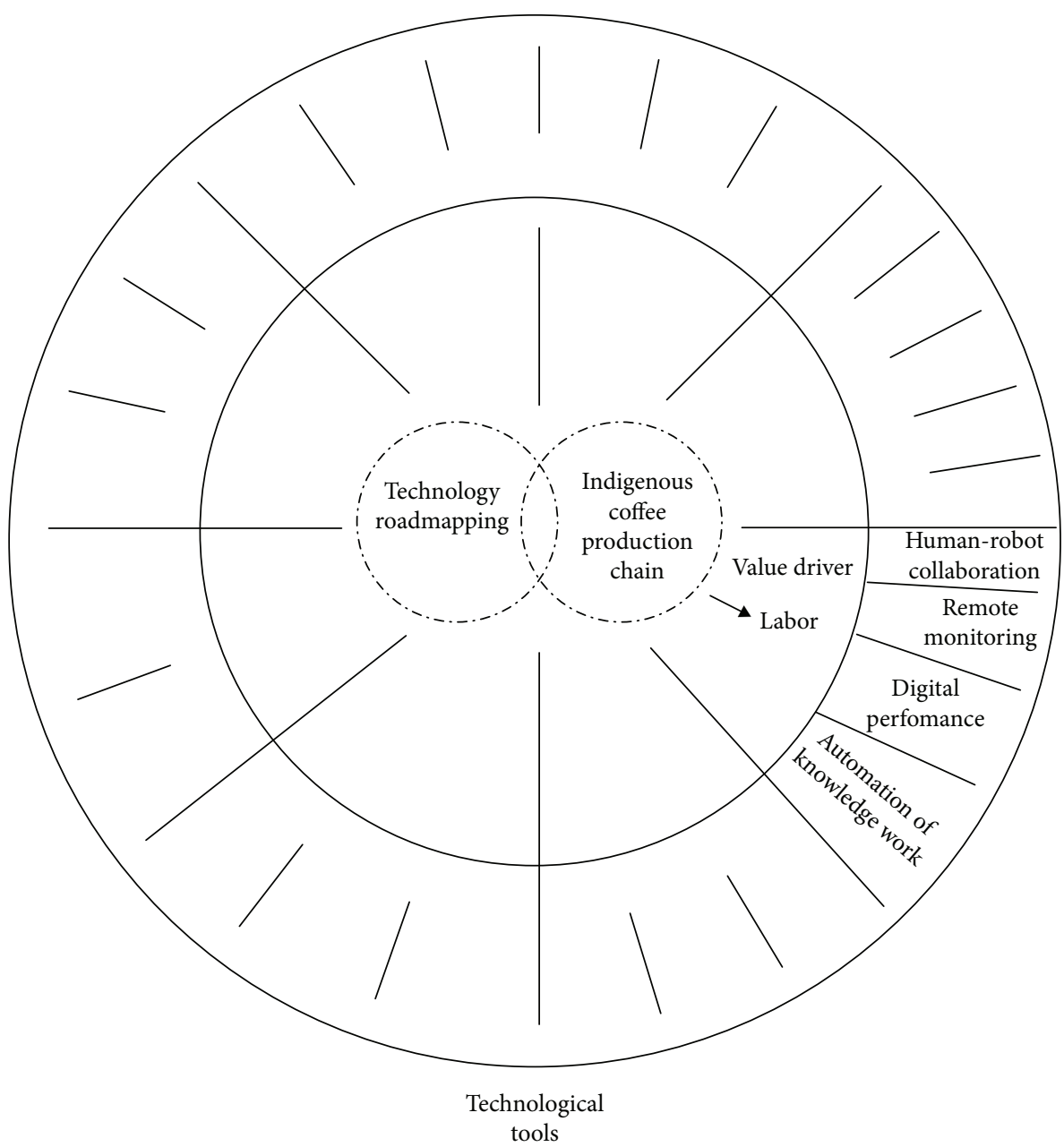

FIgURE 5: Digital compass. Description of technological tools of the labor value driver of industry 4.0. Extracted from [64].

For example, the climatic variables of the greenhouse where coffee is placed can be controlled and managed through remote sensor modules. Collecting data about temperature, humidity, and light intensity, this information can be transmitted through $\mathrm{Wi}$ - $\mathrm{Fi}$, to be versatile, to the module and can be interpreted by the experts or growers to monitor the proper growth of the plant according to quality required by the buyers [85]. Due to its feasibility, a sensor can be added to take digital images to monitor the status of the plant through image processing techniques such as those done by [86] and to decide the correct time for replanting in the open field (see Figure 7). 


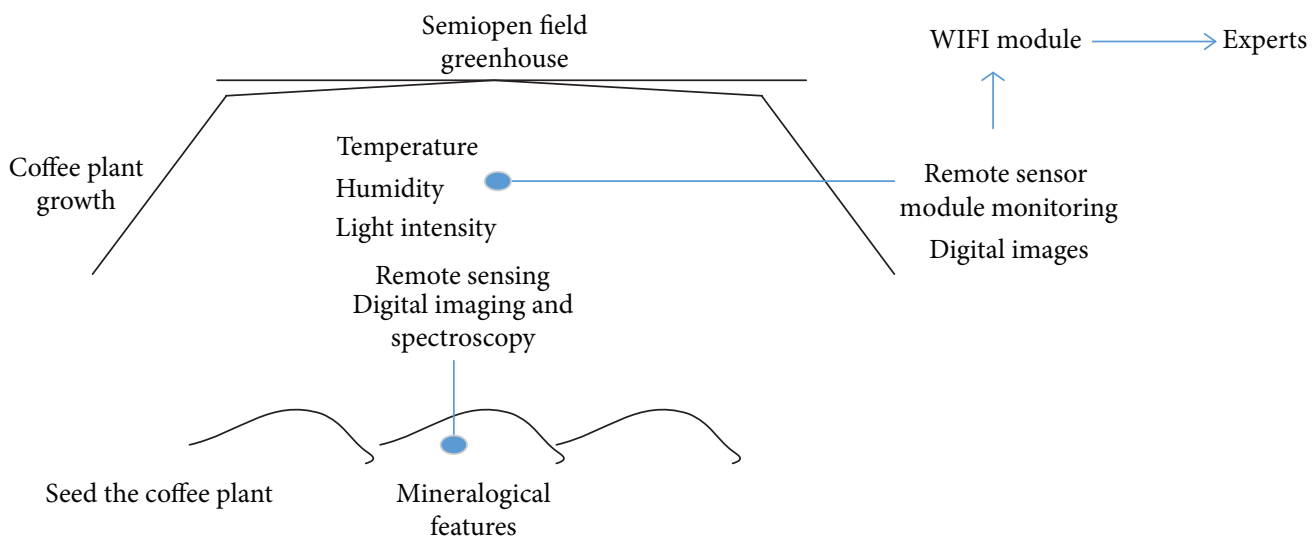

FIGURE 6: Future, present, and technology roadmapping. Description of technological routes to reach the desired future since current status of the indigenous coffee production chain from Paraje Montero and Tierra Colorada, Guerrero, Mexico.

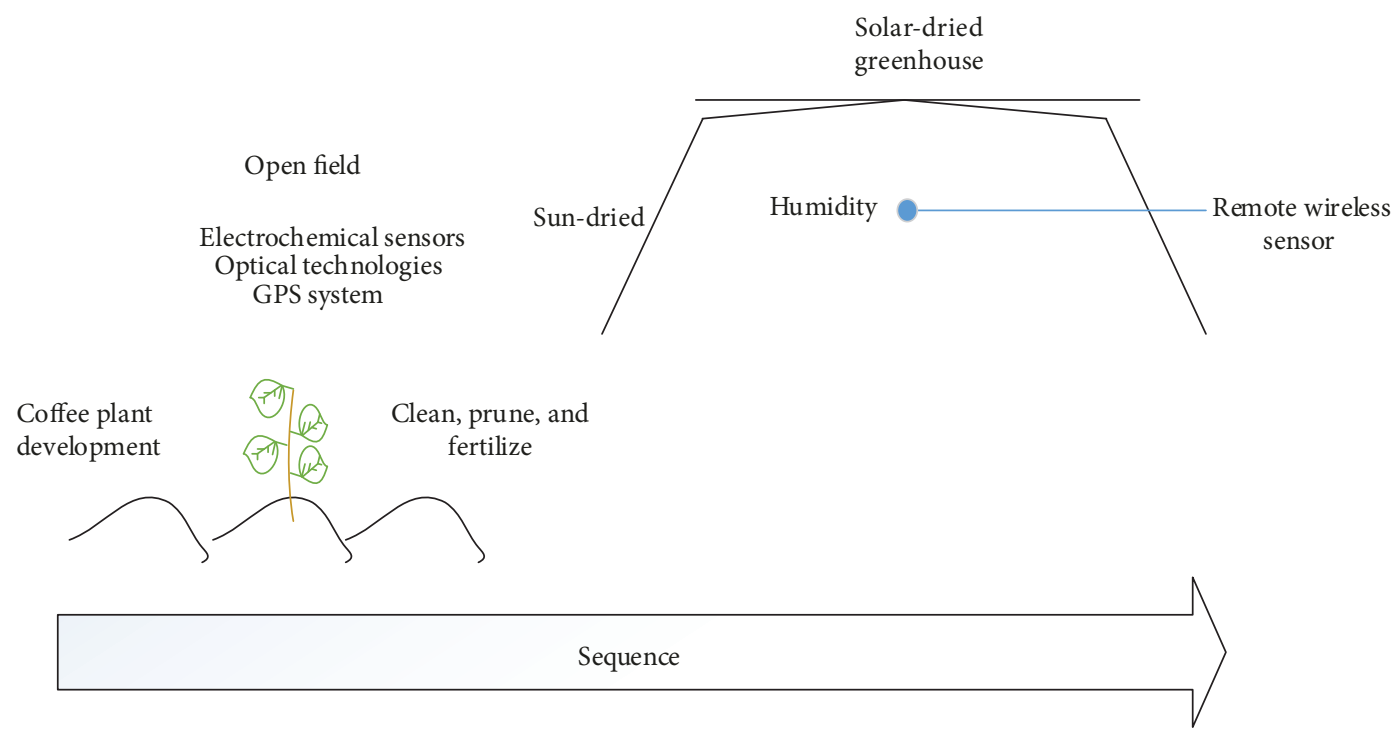

FiguRE 7: Description of emerging technologies for the greenhouse in the stages of cultivation and growth, according to indigenous coffee production chain requirements.

(b) Once the plant is in the open field, good agricultural practices (GAP) and visual strategy can be implemented to decide correct time to clean, prune, and fertilize the coffee plant. Basing on that, GAP shares the ideas of robotics technology, electrochemical sensors, and optical technologies that can be used combined with the GPS system, to assess the presence of the pest for the fertilizer application and decide the time to clean and prune [87]

(c) For the stage of sun drying, the greenhouse solar drying could be used, to reduce the time of the current sun drying process [88], combined with the use of the Wi-Fi humidity sensor to remotely and wirelessly assess and preserve an adequate moisture of the coffee cherry (see Figure 8)

(2) Knowledge and Technology Management Networks. According to the lack of infrastructure for coffee processing specifically grinding and roasting, location, producer age, and labor-intensive system, the knowledge management networks could be the most relevant strategy in the short term (see Figure 6). The combination of knowledge and technology tries to articulate coffee production from Paraje Montero and Tierra Colorada with grinding and roasting technologies of associations or local companies. This formula has been developed successfully in Oaxaca, Mexico, through association of indigenous coffee producers from this state with the Union of Indigenous Communities of the Isthmus Region (UCIRI). The case of UCIRI and indigenous coffee producers has supported the opening of commercialization channels and increased the price of coffee, and access to productive credits and inclusive training in cultivation and pruning practices have been managed.

For the above, several studies have been carried out to attend similar problems and characteristics of the crop as those of the indigenous coffee production chain from 


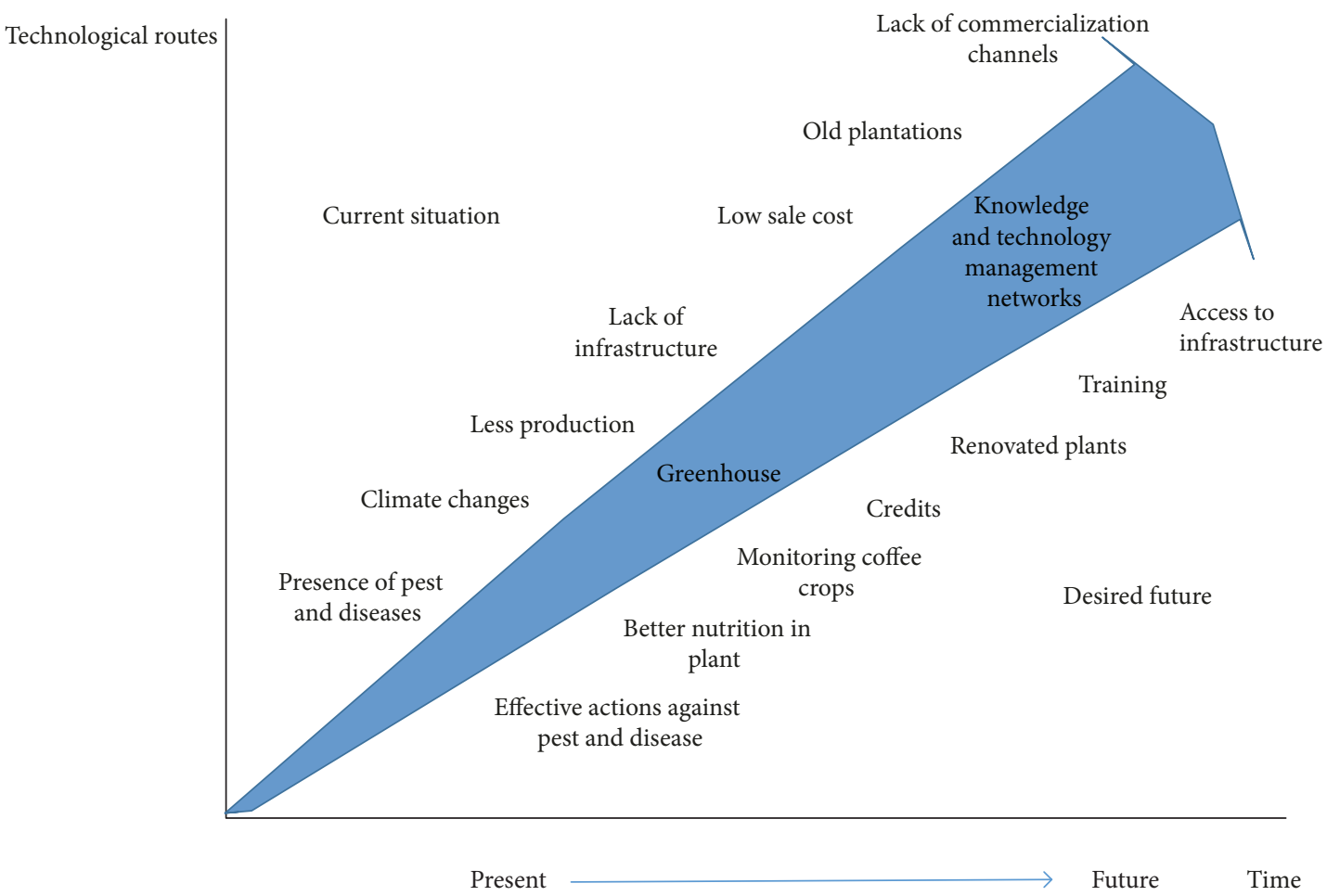

FIGURE 8: Description of emerging technologies for the greenhouse in the stages of cleaning, pruning, fertilizing, and drying, according to indigenous coffee production chain requirements.

Paraje Montero and Tierra Colorada, which could be considered for implementation in this region. This is the sense of [89]; this work could be used for greenhouse construction, control of climatic variables and knowledge, and technology management in a low-cost greenhouse. Presented in [90] is a methodology that could be used to save money and to improve the operability of the greenhouse through water and energy saving by using adequate irrigation systems. In [91] is a work that could be used for developing automatic monitoring and recording of climatic variables and increasing the quality of the coffee in the regions analyzed. Presented in [92] is a work that can be used for improving quality of coffee and by consequence increase the economic gains of producers. Related to disease management, presented in [93] is a methodology that could help in resolving some problems with coffee diseases (see Table 2).

\section{Conclusions}

Currently, worldwide technologies have been identified as a means of knowledge integration; however, for small producers, such as the here presented indigenous coffee producers of Paraje Montero and Tierra Colorada from Guerrero, Mexico, and other similar populations and producers, this has not happened yet.

Basing on previous results, greenhouse technology seems to be the most accepted by indigenous coffee producers from Paraje Montero and Tierra Colorada from Guerrero, Mexico, and if to greenhouse technology remote sensing with digital imaging and spectroscopy is added to explore mineralogical features of soil, sensor modules are added to collect data about temperature, humidity, and light intensity, electrochemical sensors and optical technologies are added to assess the presence of diseases in the coffee plant, and greenhouse solar dryers are installed to reduce the time of the sun drying process and protect the coffee cherry, it could reduce the negative effects of coffee plant diseases, climate change, lack of infrastructure, old plantations, and lack of commercialization channels and consequently, improve the coffee production level from Paraje Montero and Tierra Colorada from Guerrero, Mexico.

Therefore, it is necessary to consider emerging technologies not only because greenhouse technology is an explicit request of indigenous coffee producers from Paraje Montero and Tierra Colorada, from Guerrero, Mexico, but also because this kind of technology could be equipped by different technologies of agriculture precision, and with this, promote the knowledge and technological management networks through the communications with experts.

The study contributes to identify the problems of the indigenous coffee production chain from Paraje Montero and Tierra Colorada, from Guerrero, Mexico, and present a technology roadmap proposing technological implements according to indigenous coffee production chain requirements.

Even if the study was developed in situ and the requirement of indigenous coffee producers is greenhouse installation for effective actions against diseases of coffee and to reduce the effects of climate change, lack of infrastructure, old plantations, and lack of commercialization channels, the results should still be taken with caution. More studies should be developed with a greater 
TABLE 2: Studies that have been carried out and could be considered to attend problems of the indigenous coffee production chain from Paraje Montero and Tierra Colorada, Guerrero, Mexico.

\begin{tabular}{|c|c|c|c|c|}
\hline References & Description & Attended problems & Dedicated people & Analysis \\
\hline [89] & $\begin{array}{l}\text { This paper presented a preliminary } \\
\text { design of a low-cost greenhouse } \\
\text { which includes rainwater catchments, } \\
\text { photovoltaic cell, and battery array to } \\
\text { power electronics and pumping. The } \\
\text { greenhouse is covered by } \\
\text { polyethylene and has an Arduino- } \\
\text { based system for monitoring variables } \\
\text { such as temperature, humidity, and } \\
\text { soil moisture }\end{array}$ & $\begin{array}{l}\text { (i) Greenhouse } \\
\text { creation } \\
\text { (ii) Control of climatic } \\
\text { variables } \\
\text { (iii) Knowledge and } \\
\text { technology } \\
\text { management }\end{array}$ & $\begin{array}{l}\text { People outside of } \\
\text { Nairoby, Kenya }\end{array}$ & $\begin{array}{l}\text { The system presented here has high } \\
\text { possibility to be implemented by the } \\
\text { two populations of Guerrero, } \\
\text { México, because attended in [89] are } \\
\text { similar problems related to } \\
\text { productivity and with variability of } \\
\text { weather; also, a high percentage of } \\
\text { people are employed in agriculture } \\
\text { and do not have access to adequate } \\
\text { food supply. Also, the cost of the } \\
\text { system is low which makes these } \\
\text { developments economically } \\
\text { reachable for the two populations }\end{array}$ \\
\hline
\end{tabular}

The irrigation systems in southeast of Spain are relatively costly, and the agriculture technology level is

This paper presents an analysis of different levels of automation of WUAs (water user associations), and according to the automation level, which represents investments that go from $1.24 \%$ to $6.72 \%$, the energy saving goes from 2.05 to $8.21 \%$ and related to water savings from $0.71 \%$ to $6.56 \%$. In the majority of cases, the amortization period is less than 1.5 years (i) Water and energy saving

(ii) Money saving

(iii) Adequate irrigation of crops
Person and producers situated in the southeast of Spain relatively high. The systems here analyzed have the possibility to be implemented depending on the degree of economic power of each producer in the two regions of Guerrero, México, analyzed in this work in order to save energy, water, and money. The reason is that the level of technology implemented in several WUAs varies directly with the cost, and may be the adequate WUAs for the two populations of Guerrero, Mexico, analyzed in this work are the cheapest

This paper presents a low-cost module for climate variable monitoring; these variables are $\mathrm{CO}_{2}$, $\mathrm{pH}$, humidity, temperature, and luminosity. The equipment accounts with solar panel and Xbee as the transmission device, which according to [96] is the best low-cost wireless transmission devices used for applications in precision agriculture. This system permits users, which were from Azuay, Ecuador, to keep

historical records of their coffee crops, allowing them to access to data via user-friendly access and web tools (i) Automatic monitoring for preventive action

(ii) Increase the quality and yield of coffee crops

(iii) Keep record of climatic variables of their coffee crops
Small farmers and families' producers of coffee from Santa

Isabel in Azuay, Ecuador

The people who implemented this low-cost technology live and work in similar conditions such as the two populations analyzed in this manuscript. Almost all farmers' crops are familiar or have small plantations; it is difficult for them to access technology to monitor their cultivation, and the crop's surface to implement the technological development is difficult. Therefore, the system developed in [91] has high viability to be implemented and used by the two populations of Guerrero, Mexico, analyzed in the manuscript

The system here proposed is to be

This manuscript presents an evaluation at the industrial scale of the roasting degree of coffee beans by using the electronic nose, $L$ value of colorimetric sensor, and stepwise backward selection. Here the $L$ value of CIELab domain was positively correlated with the values of the selected electronic nose with an $R^{2}$ ranging in the interval that goes from 0.994 to 0.999

(i) Coffee quality (aroma and flavor)

(ii) Lack of infrastructure for coffee processing

(iii) Low-cost sale by kilogram (due to the increase of quality by using this technology)
Industry of coffee in Bari, Italy used at the industry scale; therefore, it is difficult to be used by the two populations of Guerrero, Mexico, analyzed in this manuscript even though it was mentioned in the work that the methodology here proposed is cheap. Maybe if the populations work together as only one industry, this methodology can be implemented to increase the quality and increase the price of their products 
TABLE 2: Continued.

\begin{tabular}{|c|c|c|c|c|}
\hline References & Description & Attended problems & Dedicated people & Analysis \\
\hline [93] & $\begin{array}{l}\text { This work presents an evaluation of } \\
\text { the potential of Sentinel- } 2 \text { MSI to } \\
\text { discriminate coffee leaf rust in crops } \\
\text { by using random forest (RF) and } \\
\text { partial least squares discriminant } \\
\text { analysis (PLS-DA); by using these two } \\
\text { methods, the authors identify spectral } \\
\text { bands and vegetation index to } \\
\text { discriminate the coffee leaf rust from } \\
\text { crops. The results suggest that this } \\
\text { system can be used to discriminate } \\
\text { correctly the coffee leaf rust from } \\
\text { crops with a discrimination accuracy } \\
\text { of } 82.5 \%\end{array}$ & $\begin{array}{l}\text { (i) Presence of pest } \\
\text { and diseases in } \\
\text { coffee crops } \\
\text { (ii) Lack of } \\
\text { infrastructure } \\
\text { (iii) Automation of } \\
\text { disease detection } \\
\text { labor }\end{array}$ & $\begin{array}{l}\text { Producers and coffee } \\
\text { researches in } \\
\text { Chipinge, Zimbabwe }\end{array}$ & $\begin{array}{l}\text { Even though the study was done } \\
\text { principally by researches in } \\
\text { Zimbabwe, the system developed by } \\
\text { [93] presents a good discrimination } \\
\text { accuracy; therefore, it can help to } \\
\text { solve the problem of disease on coffee } \\
\text { present in the two populations from } \\
\text { Guerrero, Mexico, analyzed in this } \\
\text { work. However, the cost of this } \\
\text { technology commonly results costly, } \\
\text { and it needs a trained staff to achieve } \\
\text { the data analysis [97]; therefore, it is } \\
\text { difficult to adopt this kind of } \\
\text { technology by these two populations } \\
\text { here in Mexico }\end{array}$ \\
\hline
\end{tabular}

representative producer and under different approaches; notwithstanding, this work can be used to help to determine what kind of technology has greater possibilities to be implemented in similar regions and populations than those analyzed in this work to help in solving problems elucidated by the technological roadmapping presented in this manuscript. The study serves as support for future studies in indigenous regions and for decision-making of authorities.

\section{Data Availability}

The information used to support the findings of this study are restricted by the National Council for Science and Technology from Mexico (Consejo Nacional de Ciencia y Tecnología), according to the Federal Law on Transparency and Access to Public Information in Mexico. To know the access requirements, you must contact the Technical Secretary of Transparency Committee, e-mail: ley_transparencia@conacyt.mx.

\section{Conflicts of Interest}

The authors declare that there is no conflict of interest.

\section{Acknowledgments}

The authors thank the support of the National Council for Science and Technology from Mexico (Consejo Nacional de Ciencia y Tecnología (CONACYT)), especially to the program "Catedras CONACYT." The research was supported by the National Council for Science and Technology of Mexico (Consejo Nacional de Ciencia y Tecnología (CONACYT)), under the project titled "Production and exploitation of coffee. Systemic prospection of chain value in the states of Chiapas, Oaxaca and Guerrero," with ID 2015-01-1011.

\section{Supplementary Materials}

Supplementary material is attached. These are supporting macro and individual level results; tacit knowledge becomes evident through explicit knowledge exposed on the technological route. (Supplementary Materials)

\section{References}

[1] M. Sachon, "Cuando las personas y maquinas trabajan juntos. Los cinco puntales de la cadena de valor en la industria 4.0 [When the people and machines work together. The five stanchions of the value chain in the industry 4.0]," IESE Insigth, vol. Second Quarter 2017, no. 3, pp. 15-22, 2017.

[2] T. K. Sung, "Industry 4.0: a Korea perspective," Technological Forecasting and Social Change, vol. 132, pp. 40-45, 2018.

[3] A.-T. Braun, E. Colangelo, and T. Steckel, "Farming in the era of Industrie 4.0," Procedia CIRP, vol. 72, pp. 979-984, 2018.

[4] United Nations Industrial Development Organization (UNIDO), "Industry 4.0 opportunities behind the challenge. Background paper," in UNIDO General Conference 17, pp. 156, Vienna, Austria, 2017, https://www.unido.org/sites/ default/files/files/2017-11/UNIDO\%20Background\% 20Paper\%20on\%20Industry\%204.0_27112017.pdf.

[5] United Nations, "World population projected to reach 9.8 billion in 2050, and 11.2 billion in 2100," Report news, New York, NY, USA, June 2017, https://www.un.org/development/desa/ en/news/population/world-population-prospects-2017.html.

[6] Banco Mundial, "Pobreza. Panorama general [Poverty. General view]," Report, Washington, DC, USA, September 2018, https://www.bancomundial.org/es/topic/poverty/overview.

[7] International Labour Organization, "Indigenous peoples and climate change. From victims to change agents through decent work," Report, International Labour Office, Gender, Equality and Diversity Branch, Geneva, Switzerland, 2017, https:// www.ilo.org/global/topics/indigenous-tribal/WCMS_551189/ lang-en/index.htm.

[8] R. Z. Ahmed, R. C. Biradar, and S. S. Chaudhari, "Clusterbased data aggregation for pest identification in coffee plantations using wireless sensor networks," Computers \& Electrical Engineering, vol. 56, pp. 591-607, 2016. 
[9] S. Y. Kim and B. S. Kang, "A colorimetric sensor array-based classification of coffees," Sensors and Actuators B: Chemical, vol. 275, pp. 277-283, 2018.

[10] A. S. Bosselmann, K. Dons, T. Oberthur, C. S. Olsen, A. Ræbild, and H. Usma, "The influence of shade trees on coffee quality in small holder coffee agroforestry systems in Southern Colombia," Agriculture, Ecosystems \& Environment, vol. 129, no. 1-3, pp. 253-260, 2009.

[11] B. Cheng, A. Furtado, H. E. Smyth, and R. J. Henry, "Influence of genotype and environment on coffee quality," Trends in Food Science \& Technology, vol. 57, pp. 20-30, 2016.

[12] N. Barié, M. Bücking, U. Stahl, and M. Rapp, "Detection of coffee flavour ageing by solid-phase microextraction/surface acoustic wave sensor array technique (SPME/SAW)," Food Chemistry, vol. 176, pp. 212-218, 2015.

[13] C. M. Webber and P. Labaste, Building Competitiveness in Africa's Agriculture: A Guide to Value Chain Concepts and Applications, World Bank, Washington, DC, USA, 2009.

[14] S. K. Lowder, J. Skoet, and T. Raney, "The number, size, and distribution of farms, smallholder farms, and family farms worldwide," World Development, vol. 87, pp. 16-29, 2016.

[15] International Coffee Organization (ICO), "Annual Review 2016/17," Report, London, UK, 2018, http://www.ico.org/ documents/cy2017-18/annual-review-website-e.pdf.

[16] M. Pendergrast, Uncommon Grounds. The History of Coffee and How It Transformed Our World, Basic Books, New York, NY, USA, 2010.

[17] J. G. Dórea and T. H. M. da Costa, "Is coffee a functional food?," British Journal of Nutrition, vol. 93, no. 06, pp. 773782, 2005.

[18] P. Paiva, "Economic and social development in Latin America: the role of coffee," in World Coffee Conference, pp. 1-12, London, UK, May 2000, http://www.ico.org/event_pdfs/paiva.pdf.

[19] ECOSUR, "Datos nuestro contexto [Data our context]," Report, 2017, https://www.ecosur.mx/giezca/wp-content/uploads/sites/ 11/2017/08/DatosCafe.pdf.

[20] International Coffee Organization (ICO), "Identifying coffee sector challenges in selected Central American countries and Mexico," Projects Committee 15th meeting, Mexico City, Mexico, March 2018, http://www.ico.org/documents/cy201718/pj-120e-challenges-central-america-mexico.pdf.

[21] I. Alvarado, Alta calidad y rendimientos. Invernaderos automatizados para optimizar la producción de jitomate [High quality and performance. Automated greenhouses to optimize the production of tomato], Gaceta UNAM, 2018.

[22] H. Van Es and J. Woodard, "Innovation in agriculture and food systems in the digital age," in The Global Innovation Index 2017. Innovation Feeding the World, pp. 97-104, Cornell University, INSEAD and WIPO, 2017.

[23] A. L. Porter, W. B. Ashton, G. Clar et al., "Technology futures analysis: toward integration of the field and new methods," Technological Forecasting and Social Change, vol. 71, no. 3, pp. 287-303, 2004.

[24] R. Phaal, C. J. P. Farrukh, and D. R. Probert, "Technology roadmapping-a planning framework for evolution and revolution," Technological Forecasting and Social Change, vol. 71, no. 1-2, pp. 5-26, 2004.

[25] R. Phaal and G. Muller, "An architectural framework for roadmapping: towards visual strategy," Technological Forecasting and Social Change, vol. 76, no. 1, pp. 39-49, 2009.
[26] Y. Zhang, D. K. R. Robinson, A. L. Porter, D. Zhu, G. Zhang, and J. Lu, "Technology roadmapping for competitive technical intelligence," Technological Forecasting and Social Change, vol. 110, pp. 175-186, 2016.

[27] J. A. Schumpeter, The Theory of Economic Development, Routledge, New York, NY, USA, 2017.

[28] Q. Zhao and J. Huang, "Roadmap of resource saving agricultural science and technology development," in Agricultural Science \& Technology in China: A Roadmap to 2050, pp. 8099, Springer, Berlin, Heidelberg, 2011.

[29] Comisión Nacional del Agua (CONAGUA), “Atlas del agua en México 2015 (Atlas of wáter in Mexico 2015),” 2015, http:// www.conagua.gob.mx/CONAGUA07/Publicaciones/ Publicaciones/ATLAS2015.pdf.

[30] G. Acosta-García, A. M. Chapa-Oliver, J. R. Millán-Almaraz et al., "CaLEA 73 gene from Capsicum annuum L. enhances drought and osmotic tolerance modulating transpiration rate in transgenic Arabidopsis thaliana," Canadian Journal of Plant Science, vol. 95, no. 2, pp. 227-235, 2015.

[31] C. W. Holsapple and M. Singh, "The knowledge chain model: activities for competitiveness," Expert Systems with Applications, vol. 20, no. 1, pp. 77-98, 2001.

[32] I. Nonaka, R. Toyama, and N. Konno, "SECI, $B a$ and leadership: a unified model of dynamic knowledge creation," Long Range Planning, vol. 33, no. 1, pp. 5-34, 2000.

[33] P. Quintas, P. Lefrere, and G. Jones, "Knowledge management: a strategic agenda," Long Range Planning, vol. 30, no. 3, pp. 385-391, 1997.

[34] Y. Wu, D. Senoo, and R. Magnier-Watanabe, "Diagnosis for organizational knowledge creation: an ontological shift SECI model," Journal of Knowledge Management, vol. 14, no. 6, pp. 791-810, 2010.

[35] A. Calvo-Mora, A. Navarro-García, and R. Periañez-Cristobal, "Project to improve knowledge management and key business results through the EFQM excellence model," International Journal of Project Management, vol. 33, no. 8, pp. 1638-1651, 2015.

[36] J. Lindblom, C. Lundström, M. Ljung, and A. Jonsson, "Promoting sustainable intensification in precision agriculture: review of decision support systems development and strategies," Precision Agriculture, vol. 18, no. 3, pp. 309-331, 2017.

[37] Food and Agriculture Organization, "FAO Knowledge Strategy," Report, March 2011, http://www.fao.org/fileadmin/ user_upload/capacity_building/KM_Strategy.pdf.

[38] D. el Chami and M. E. Moujabber, "Drought, climate change and sustainability of water in agriculture: a roadmap towards the NWRS2," South African Journal of Science, vol. 112, no. 9/10, pp. 1-4, 2016.

[39] G. Cardenas-Manríquez, I. Vega-Muñoz, A. L. VillagómezAranda et al., "Proteomic and metabolomic profiles in transgenic tobacco (N. tabacum xanthi nc) to CchGLP from Capsicum chinense BG-3821 resistant to biotic and abiotic stresses," Environmental and Experimental Botany, vol. 130, pp. 33-41, 2016.

[40] J. R. Millan-Almaraz, R. D. J. Romero-Troncoso, R. G. Guevara-Gonzalez et al., "FPGA-based fused smart sensor for real-time plant-transpiration dynamic estimation," Sensors, vol. 10, no. 9, pp. 8316-8331, 2010.

[41] S. Islam, M. Lefsrud, J. Adamowski, B. Bissonnette, and A. Busgang, "Design, construction, and operation of a demonstration rainwater harvesting system for greenhouse irrigation 
at McGill University, Canada," HortTechnology, vol. 23, no. 2, pp. 220-226, 2013.

[42] M. Greco, A. Chiappetta, L. Bruno, and M. B. Bitonti, "In posidonia oceanica cadmium induces changes in DNA methylation and chromatin patterning," Journal of Experimental Botany, vol. 63, no. 2, pp. 695-709, 2012.

[43] J. Gutierrez, J. F. Villa-Medina, A. Nieto-Garibay, and M. A. Porta-Gandara, "Automated irrigation system using a wireless sensor network and GPRS module," IEEE Transactions on Instrumentation and Measurement, vol. 63, no. 1, pp. 166-176, 2014.

[44] J. Singh, "A roadmap for production of sustainable, consistent and reliable electric power from agricultural biomass-an Indian perspective," Energy Policy, vol. 92, pp. 246-254, 2016.

[45] M. S. Umar, T. Urmee, and P. Jennings, “A policy framework and industry roadmap model for sustainable oil palm biomass electricity generation in Malaysia," Renewable Energy, vol. 128, pp. 275-284, 2018.

[46] H. J. Jeon, Y. K. Choi, K. G. Song et al., "Development of a photoelectrochemical sensor for monitoring algal biomass (Chlorella vulgaris)," Sensors and Actuators B: Chemical, vol. 185, pp. 405-410, 2013.

[47] S. Pullano, M. G. Bianco, C. Critello et al., "Biomass plant and sensors network for process monitoring and energy storage in a superconducting magnetic device," Safety of Technogenic Environment, vol. 6, pp. 28-35, 2015.

[48] International Coffee Organization (ICO), "Five-year action plan for the International Coffee Organization," International Coffee Council 120th Session, Yamoussoukro, Cote d'Ivoire, September 2017, http://www.ico.org/documents/cy2016-17/ icc-120-11e-five-year-action-plan.pdf.

[49] International Coffee Organization (ICO), "Building a sustainable and inclusive coffee sector in Uganda (project summary)," Projects Committee/International Coffee Council, London, UK, September 2018, http://www.ico.org/documents/cy201718/pj-124e-uganda-project-summary.pdf.

[50] Republic of the Philippines, Department of Agriculture, Regional Field Unit XII, "Coffee road map," Report, http://rfu12.da.gov.ph/ attachments/article/313/Coffee\%20Roadmap.pdf.

[51] CAB International (CABI), "Boosting coffee productivity in Kenya," Report, February 2017, https://www.cabi.org/projects.

[52] S. Pongnumkul, P. Chaovalit, and N. Surasvadi, "Applications of smartphone-based sensors in agriculture: a systematic review of research," Journal of Sensors, vol. 2015, Article ID 195308, 18 pages, 2015.

[53] International Fund for Agricultural Development (IFAD), "IFAD's Medium-term Cooperation Programme with Farmers' Organizations Phase Two (MTCP2)," Asia-Pacific Farmers' Forum, Rome, Italy, October 2017, https://www.ifad .org/documents/38714170/39148759/MTCP2_apr.pdf/ d9ca7f99-1c5e-4925-8962-d02646b66934.

[54] International Institute for Environment and Development (IIED), "Sustainable land management technologies," Report climate change, London, UK, 2011, https://www.iied.org/ sustainable-land-management-technologies.

[55] M. Córdoba, C. Bruno, M. Balzarini, and J. L. Costa, “Análisis de componentes principales con datos georreferenciados: Una aplicación en agricultura de precisión [Principal component analysis with georeferenced data: an application in precision agriculture]," Revista de la Facultad de Ciencias Agrarias. Universidad Nacional del Cuyo, vol. 44, no. 1, pp. 27-39, 2012.
[56] R. C. Bispo, R. A. C. Lamparelli, and J. V. Rocha, "Using fraction images derived from modis data for coffee crop mapping," Engenharia Agrícola, vol. 34, no. 1, pp. 102-111, 2014.

[57] B. Hernández-Vera, A. A. Aguilar Lasserre, M. Gastón Cedillo-Campos, L. E. Herrera-Franco, and J. Ochoa-Robles, "Expert system based on fuzzy logic to define the production process in the coffee industry," Journal of Food Process Engineering, vol. 40, no. 2, article e12389, 2017.

[58] Z. Sai, Y. Fan, T. Yuliang, X. Lei, and Z. Yifong, "Optimized algorithm of sensor node deployment for intelligent agricultural monitoring," Computers and Electronics in Agriculture, vol. 127, pp. 76-86, 2016.

[59] R. Ali, A. K. Pal, S. Kumari, M. Karuppiah, and M. Conti, "A secure user authentication and key-agreement scheme using wireless sensor networks for agriculture monitoring," Future Generation Computer Systems, vol. 84, pp. 200-215, 2018.

[60] G. Pandey, "Challenges and future prospects of agrinanotechnology for sustainable agriculture in India," Environmental Technology \& Innovation, vol. 11, pp. 299-307, 2018.

[61] M. Quintero-Angel and A. González-Acevedo, "Tendencies and challenges for the assessment of agricultural sustainability," Agriculture, Ecosystems \& Environment, vol. 254, pp. 273-281, 2018.

[62] N. Osorio, "Technological development in coffee: constraints encountered by producing countries," in Presentation to the World Food and Farming Congress, pp. 1-5, London, UK, November 2002, International Coffee Organization, http:// www.ico.org/documents/food.pdf.

[63] M. E. dos Santos and J. C. dos Santos Jesus, "Fatores que comprometem a adoção de tecnologia de informação em empresas cafeeiras," Production, vol. 15, no. 3, pp. 456-468, 2005.

[64] McKinsey Digital, "Industry 4.0. How to navigate digitization of the manufacturing sector," Report, McKinsey \& Company, 2015, https://www.mckinsey.com/business-functions/operations/ourinsights/industry-four-point-o-how-to-navigae-the-digitization-ofthe-manufacturing-sector.

[65] C. Bandera, F. Keshtkar, M. R. Bartolacci, S. Neerudu, and K. Passerini, "Knowledge management and the entrepreneur: insights from Ikujiro Nonaka's dynamic knowledge creation model (SECI)," International Journal of Innovation Studies, vol. 1, no. 3, pp. 163-174, 2017.

[66] A. Lis, "Knowledge creation and conversion in military organizations. How the SECI model is applied within armed forces," Journal of Entrepreneurship, Management and Innovation, vol. 10, no. 1, pp. 57-78, 2014.

[67] S. M. Hosseini, "The application of SECI model as a framework of knowledge creation in virtual learning," Asia Pacific Education Review, vol. 12, no. 2, pp. 263-270, 2011.

[68] Secretaría de economía, "Crafting the future. A roadmap for industry 4.0 in Mexico," Report, Mexico City, Mexico, April 2016, https://www.promexico.mx/documentos/mapas-de-ruta/ industry-4.0-mexico.pdf.

[69] Gobierno del Estado de Guerrero, Ley de reconocimiento, derechos y cultura de los pueblos y comunidades indígenas del Estado de Guerrero [Law of Recognition, Right and Culture of the Indigenous Peoples and Communities of the State of Guerrero], Nacional de los Derechos Humanos (CNDH), 2011, Marco normativo. 
[70] A. Lifshitz, "Otelo. Metáfora del diagnóstico erróneo [Othello. Metaphor of the wrong diagnosis]," Medicina Interna de México, vol. 33, no. 1, pp. 1-3, 2017.

[71] Instituto Nacional de Estadística y Geografía, "Censo de Población y Vivienda 2010 [Census of population and housing 2010]," Microdatos, localidades con menos de 5 mil habitantes, Guerrero, Mexico, 2010, http://www.beta.inegi.org.mx/ programas/ccpv/2010/.

[72] International Coffee Organization (ICO), “Aspectos botánicos [Botanical aspects]," Report, London, UK, 2018, http://www .ico.org/es/botanical_c.asp.

[73] V. M. Toledo and P. Moguel, "El café en México, ecología, cultura indígena y sustentabilidad," Ciencias, no. 43, pp. 4051, 1996.

[74] L. R. Valenciano, "Mujeres indígenas de Guerrero Xochineutl [Indigenous women of Guerrero Xochineutl]," Report History, Chilapa de Alvarez, Guerrero, Mexico, https://www.lacoperacha. org.mx/mujeres-indigenas-guerrero-xochineutl.php.

[75] PRO Ayuda a la mujer origen, AC, "Mujeres de Tlapa en el proyecto "Hilando nuestras vidas"," Report, Mexico City, Mexico, April 2018, https://www.origenac.org/index.php/ noticias/noticias-origen/item/414-mujeres-de-tlapa-en-elprograma-hilando-nuestras-vidas.

[76] E. Benítez-García, J. L. Jaramillo-Villanueva, S. Escobedo-Garrido, and S. Mora-Flores, "Caracterización de la producción y del comercio de café en el municipio de Cuetzalan, Puebla," Agricultura Sociedad y Desarrollo, vol. 12, no. 2, pp. 181-198, 2015.

[77] G. C. Brenes and C. S. Víquez, "Medio ambiente y sostenibilidad," in La situación y tendencias de la producción de café en América Latina y el Caribe, IICA San José Costa Rica, Centro de Investigación y Asistencia en Tecnología y Diseño del Estado de Jalisco, AC, Guadalajara, México, 2016.

[78] F. Celis, "Precios del café,” Report, Convención Nacional del Sistema Producto Café, August 2018, https://amecafe.org.mx/ wp-content/uploads/2018/08/PRECIOS-DEL-CAFE.pdf.

[79] J. F. Barrera, "Broca y roya del café, viejos problemas, nuevos enfoques," Ciencia y Desarrollo, vol. 284, 2016.

[80] M. D. R. Ayala-Carrillo, E. Zapata-Martelo, B. Suárez-San Román, and A. Nazar-Beautelspacher, "Estrategias de reproducción familiar en las fincas cafetaleras del soconusco, Chiapas," Agricultura Sociedad y Desarrollo, vol. 11, no. 3, pp. 401423, 2014.

[81] T. Titataniske, Procesamiento habitual del café en Cuatzalan, Puebla, Revista vinculando, 2014.

[82] Y. Chen, B. Huang, W. Hu, D. C. Weindorf, X. Liu, and L. Yang, "Accumulation and ecological effects of soil heavy metals in conventional and organic greenhouse vegetable production systems in Nanjing, China," Environmental Earth Sciences, vol. 71, no. 8, pp. 3605-3616, 2014.

[83] S. S. Khalajabadi, "Fertilidad del suelo y nutrición del café en Colombia. Guía práctica," Report no. 32, Centro Nacional de Investigaciones de Café (Cenicafe), 2008, https://www .cenicafe.org/es/publications/bot032.pdf.

[84] F. Garfagnoli, A. Ciampalini, S. Moretti, and L. Chiarantini, "Detecting clay minerals in soils through hyperspectral remote sensing," in 4th EARSeL Workshop on Remote Sensing and Geology, pp. 95-101, Mykonos, Greece, 2012.

[85] M. H. Liang, Y. F. He, L. J. Chen, and S. F. du, "Greenhouse environment dynamic monitoring system based on WIFI," IFAC-PapersOnLine, vol. 51, no. 17, pp. 736-740, 2018.
[86] L. M. Contreras-Medina, R. A. Osornio-Rios, I. TorresPacheco, R. . J. Romero-Troncoso, R. G. Guevara-González, and J. R. Millan-Almaraz, "Smart sensor for real-time quantification of common symptoms present in unhealthy plants," Sensors, vol. 12, no. 1, pp. 784-805, 2012.

[87] J. De Baerdemaeker, "Precision agriculture technology and robotics for good agricultural practices," IFAC Proceedings Volumes, vol. 46, no. 4, pp. 1-4, 2013.

[88] P. Singh, V. Shrivastava, and A. Kumar, "Recent developments in greenhouse solar drying: a review," Renewable and Sustainable Energy Reviews, vol. 82, pp. 3250-3262, 2018.

[89] B. Groener, N. Knopp, K. Korgan et al., "Preliminary design of a low-cost greenhouse with open source control systems," Procedia Engineering, vol. 107, pp. 470-479, 2015.

[90] D. G. Fernández-Pacheco, M. Ferrández-Villena, J. M. MolinaMartínez, and A. Ruiz-Canales, "Performance indicators to assess the implementation of automation in water user associations: a case study in Southeast Spain," Agricultural Water Management, vol. 151, pp. 87-92, 2015.

[91] J. Abad, J. Farez, P. Chasi et al., "Coffee crops variables monitoring: a case of study in Ecuadorian Andes," in International Conference of ICT for Adapting Agriculture to Climate Change, pp. 202-217, Cali, Colombia, 2018.

[92] P. Giungato, E. Laiola, and V. Nicolardi, "Evaluation of industrial roasting degree of coffee beans by using an electronic nose and a stepwise backward selection of predictors," Food Analytical Methods, vol. 10, no. 10, pp. 3424-3433, 2017.

[93] A. Chemura, O. Mutanga, and T. Dube, "Separability of coffee leaf rust infection levels with machine learning methods at Sentinel-2 MSI spectral resolutions," Precision Agriculture, vol. 18, no. 5, pp. 859-881, 2017.

[94] Instituto Nacional de Estadística y GeografíaFebruary 2019, https://www.inegi.org.mx/app/mapas/.

[95] México, Pueblos América, "Guerrero," 2018, https://mexico .pueblosamerica.com/guerrero/.

[96] Aqeel-ur-Rehman, A. Z. Abbasi, N. Islam, and Z. A. Shaikh, "A review of wireless sensors and networks' applications in agriculture," Computer Standards \& Interfaces, vol. 36, no. 2, pp. 263-270, 2014.

[97] O. Mutanga, T. Dube, and O. Galal, "Remote sensing of crop health for food security in Africa: potentials and constraints," Remote Sensing Applications: Society and Environment, vol. 8, pp. 231-239, 2017. 


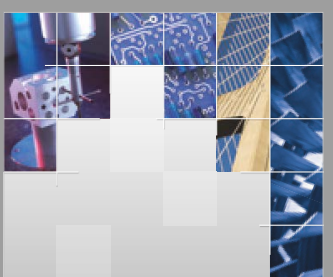

\section{Enfincering}
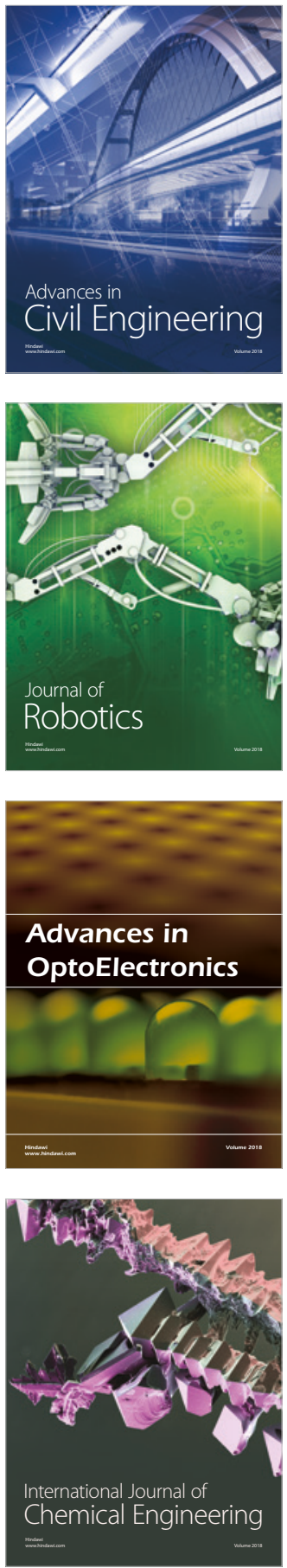

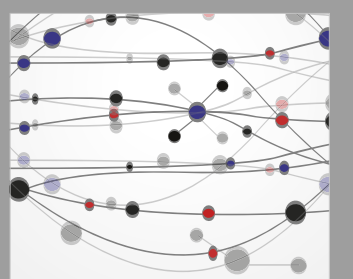

\section{Rotating \\ Machinery}

The Scientific World Journal

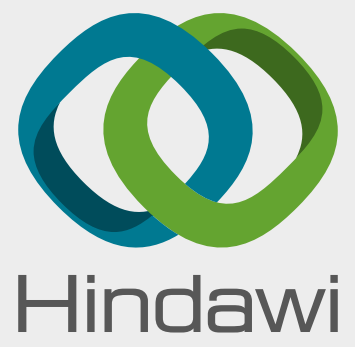

Submit your manuscripts at

www.hindawi.com
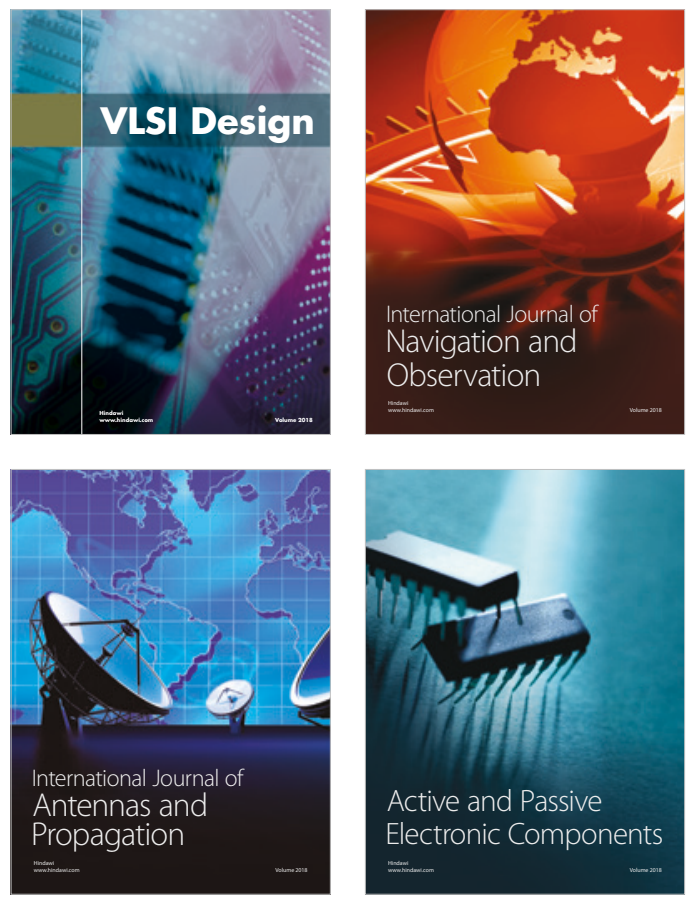
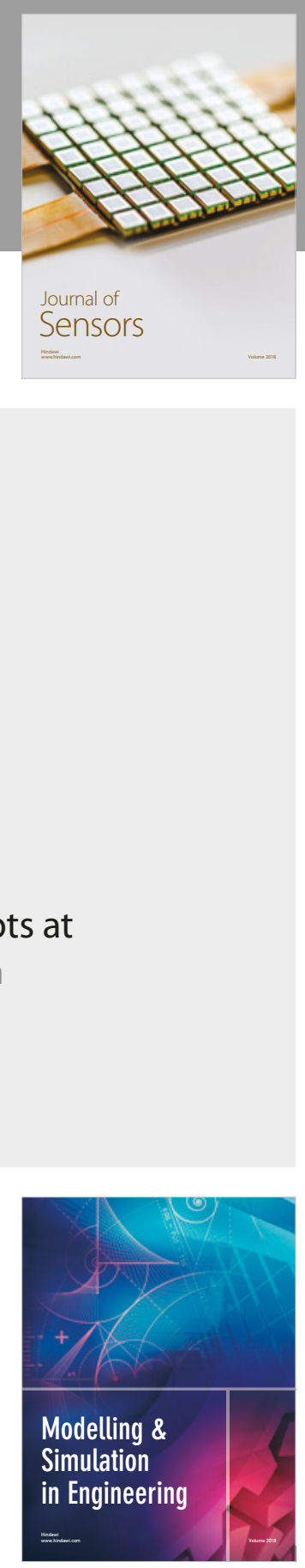

\section{Advances \\ Multimedia}
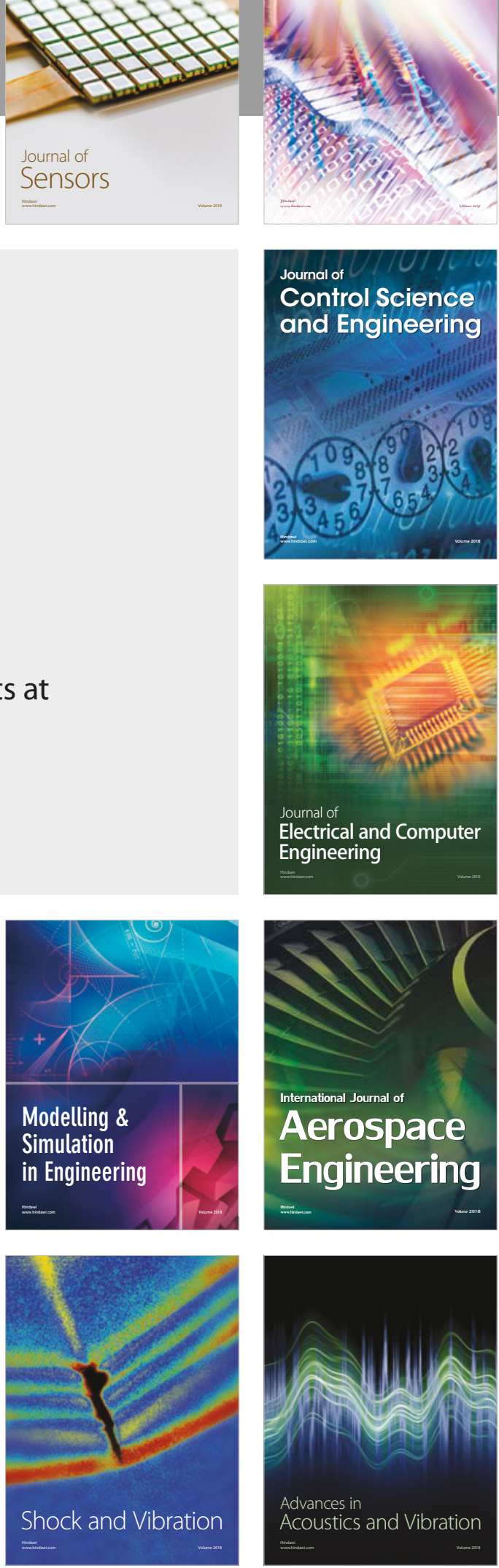